\title{
Phase Formation and Evaluation of Calcium Phosphate Ceramics Using Eggshell Waste
}

\author{
Amal M. Ibrahim ${ }^{1,2}$, M.M. Abd El-Latif* and M.M. Selim \\ ${ }^{I}$ Catalysis Laboratory, Physical Chemistry Department, \\ National Research Centre, El Buhouth St., Cairo, ${ }^{2}$ Faculty of \\ Science, University of Jeddah, Jeddah, Saudi Arabia Surface \\ Chemistry and Fabrication Technology Department, \\ Advanced Technology and New Materials Research Institute \\ (ATNMRI), City of Scientific Research and Technological \\ Applications (SRTA-City) Alexandria, Egypt.
}

\begin{abstract}
CALCIUM phosphate ceramics are considered as a family of the most important bio-inorganic materials used in biomedical applications. Calcium phosphates were prepared from eggshell waste and phosphoric acid after cleaning eggshell precursor and converting it to calcium oxide by calcination. The phases obtained from such reaction were dependent not only on the weight ratio of calcined eggshell powder and phosphoric acid $(\mathrm{Ca} / \mathrm{P})$ but also on the calcination temperature of the obtained mixture. Effects of $\mathrm{Ca} / \mathrm{P}$ ratio and calcination temperature were studied and the phases obtained were evaluated using X-Ray Diffraction spectroscopy (XRD) and Scanning Electron Microscopy (SEM).
\end{abstract}

It is well established that tricalcium phosphate salts (TCP) and hydroxyapatite (HA) play an important role in bone reconstruction and replacement, bone defect filling, drug delivery, a coating of metal prostheses and dentistry ${ }^{(1-3)}$. This role was devoted to their chemical similarity to the natural composition of bone structure $^{(4-6)}$. Several methods have been studied to synthesize calcium phosphate minerals including wet chemical precipitation ${ }^{(7,8)}$, hydrothermal method ${ }^{(9,10)}$, mechanochemical method ${ }^{(11,12)}$ and sol-gel technique ${ }^{(13,14)}$. Meanwhile, HA has a strong affinity to host hard tissues tricalcium phosphate resorbable in vivo with the new bone formation during implantation ${ }^{(15)}$. It is also well known that natural bone mineral composition contains impurities such as carbonate, chloride, fluoride, magnesium and sodium ${ }^{(16,17)}$. It was found that bone tissue contains 3$8 \%$ carbonate minerals ${ }^{(18,19)}$. This diversity in bone chemical composition encourages researchers to use natural waste precursors such as fruit waste ${ }^{(20,21)}$, eggshell ${ }^{(2,23)}$, fish bone, oyster shells and corals ${ }^{(24)}$ for the preparation of different calcium phosphate minerals. These natural sources of calcium help in mimicking natural composition of bone structure. Among these sources several attempts have been achieved to prepare calcium phosphate minerals using egg shell waste. Calcium phosphate ceramics exist in different forms and phases depending on the $\mathrm{Ca} / \mathrm{P}$ ratio and also on thermal stability. Hydroxyapatite $\mathrm{HA}$ is the most widely used calcium phosphate ceramics CPC in biomedical applications with $\mathrm{Ca} / \mathrm{P}$ ratio 1.67. HA has the most similar composition to bone structure and it is also the most thermodynamically stable one among other calcium 
phosphates ${ }^{(25)} \cdot \beta$ - Tricalcium phosphate $\mathrm{Ca} 3(\mathrm{PO} 4) 2(\beta-\mathrm{TCP})$ - also is known as $\beta$-whitlockite- is another type of $\mathrm{CPC}$ which has the advantage of being bioresorbable ceramic with a low rate of degradation and thermo-dynamically stable in temperature range $\sim 1000-1200^{\circ} \mathrm{C} . \beta$-TCP is transformed into $\alpha$ Tricalcium phosphate which is another phase of CPC at a temperature above $1200^{\circ} \mathrm{C}$. $\alpha-\mathrm{TCP}$ is not widely used in biomedical applications because it is rapidly degraded and badly resorbable ${ }^{(26)}$. In the Present study, hydrothermal preparation of calcium phosphate ceramics from eggshell using a different amount of phosphoric acid was achieved; also, the effect of different calcination temperature on the phase obtained was studied. The produced powders were characterized using X-Ray Diffraction spectroscopy (XRD) and Scanning Electron Microscopy (SEM).

\section{Experimental}

Collected raw egg-shell was carefully cleaned from both outside and inside to remove protein membrane, then dried at $100^{\circ} \mathrm{C}$ overnight. The dried raw eggshell was milled and passed through sieve mesh 100 . The produced powder was calcined at $900{ }^{\circ} \mathrm{C}$ for $3 \mathrm{hr}$ to get rid of all organic residues associated with eggshell. After that, the calcined powder was mixed with phosphoric acid in different weight ratios of powder to phosphoric acid from 1:1.2 to 1:1.8. The PH adjusted at 9-10 with ammonia solution 50\%, and then the precursors were mixed thoroughly to ensure the homogeneity. The produced mixtures were fired at different temperatures from 750 to $1050{ }^{\circ} \mathrm{C}$.

\section{Results and Discussion}

The crystal structural of the obtained CPCs was studied by X-ray diffractometry (Schimadzu-7000 diffractometer) using $\mathrm{Cu} \mathrm{K \alpha}$ radiation beam $(\lambda=0.154060 \mathrm{~nm})$, operating at $30 \mathrm{kV}$ and $30 \mathrm{~mA}$ with a copper target. Data were collected between $10^{\circ}$ and $80^{\circ}$ in $2 \theta$.

The surface morphologies were observed on a JEOL JSM 6360LA scanning electron microscope (SEM). Through sticking the ESC bead on the holder then sputtered with gold before the examination.

Figure 1 showed the X-ray diffraction patterns of the prepared powders with different $\mathrm{Ca} / \mathrm{P}$ ratio and calcined at $750^{\circ} \mathrm{C}$. It was observed that for the highest $\mathrm{Ca} / \mathrm{P}$ ratio (1.65) pattern showed pure hydroxylapatite (HA) phase with XRD pattern in agreeing with ICDD card no.9-432. As the $\mathrm{Ca} / \mathrm{P}$ ratio decreased to 1.49 HA still the predominant phase with the minor appearance of calcium pyrophosphate (Ca2P2O7) ICDD card No. 9-345 with increasing the amount of phosphoric acid added. As the $\mathrm{Ca} / \mathrm{P}$ ratio decreased to 1.33 , the pattern showed $\beta$-tricalcium phosphate was developed with pattern agree with ICDD card No. 3 690 , meanwhile in the case of $\mathrm{Ca} / \mathrm{P}$ ratio 1.29 , pyrophosphate was found to be the predominant phase with the highest amount of phosphoric acid added.

Egypt. J. Chem. 59, No. 3 (2016) 

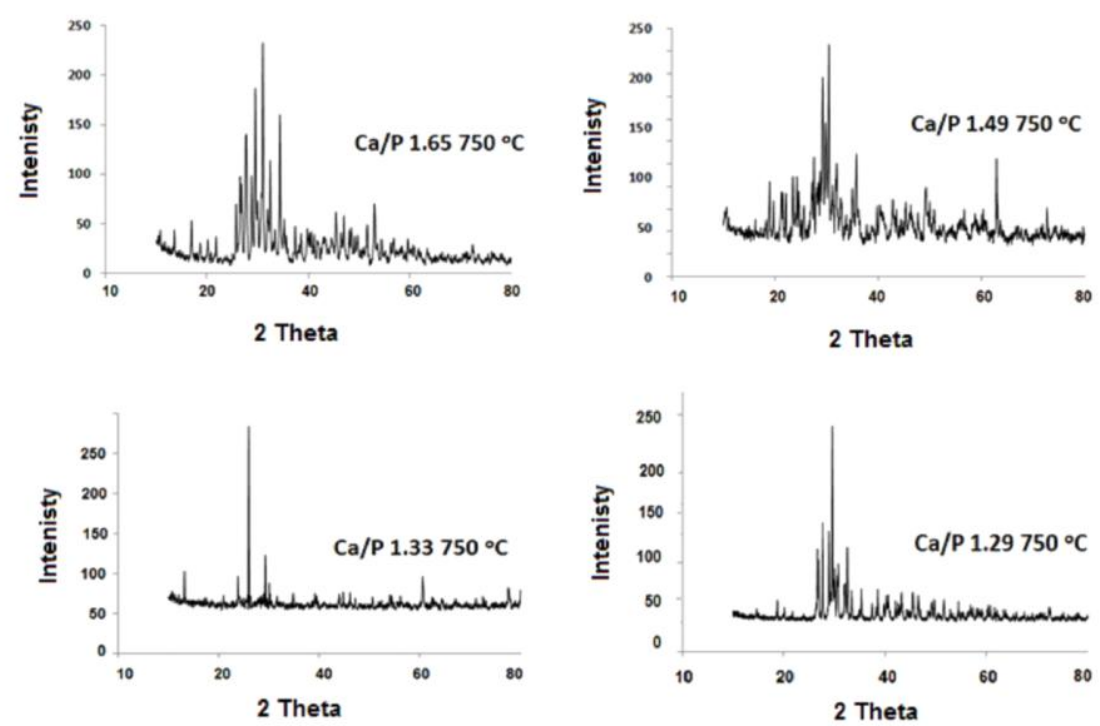

Fig. 1. X-ray diffraction of calcium phosphate ceramics prepared with $\mathrm{Ca} / \mathrm{P}$ ratio ranging from 1.65 to 1.29 and calcined at $750^{\circ} \mathrm{C}$.

As the calcination temperature increased to $900^{\circ \mathrm{C}}$ (Fig. 2) hydroxyapatite phase still the only phase developed with $\mathrm{Ca} / \mathrm{P}$ ratio 1.65 and the decrease of the $\mathrm{Ca} / \mathrm{P}$ ratio to 1.49 accompanied by the appearance of minor pyrophosphate phase with major HA existence. $\beta$ - tricalcium phosphate was the only phase detected and with further decrease in $\mathrm{Ca} / \mathrm{P}$ ratio pyrophosphate phase was the predominant phase.

Figure 3 represents samples calcined at $1050{ }^{\circ} \mathrm{C}$, at this temperature even with $\mathrm{CA} / \mathrm{P} 1.65$ the major detected phase was $\beta$ - tricalcium phosphate, and also, for $\mathrm{Ca} / \mathrm{P} 1.49$ the major phase detected was $\beta$ - TCP with the minor existence of pyrophosphate. In the case of $\mathrm{Ca} / \mathrm{P}$ ratio1.33 pure $\beta$-TCP was developed, meanwhile for $\mathrm{Ca} / \mathrm{P}$ ratio 1.29 was identified as the major phase.

Figure 4 showed the scanning electron microscopy images of the prepared samples with different $\mathrm{CA} / \mathrm{P}$ ratios and at different calcination temperatures. It was noticed that for $\mathrm{Ca} / \mathrm{P}$ ratio 1.65 (Fig. 4a-c)] the images showed for calcination temperatures $750{ }^{\circ} \mathrm{C}$ (Fig. 4a) and $900^{\circ} \mathrm{C}$ (Fig. 4b) average particle size 400 and $\sim 600 \mathrm{~nm}$, respectively. Meanwhile, for the sample fired at $1050{ }^{\circ} \mathrm{C}$ (Fig. 4c), the image showed particle size increase up to $\sim 1.5 \mu \mathrm{m}$. This increase in particle size could be devoted to the appearance of pyrophosphate phase which was cited to enhance grain enlargement through its tendency to make bridging between other calcium phosphate particles ${ }^{(26)}$. In the case of $\mathrm{Ca} / \mathrm{P}$ ratio 1.49 (Fig. 4.d-f), there was particle size increase with the increase of calcination temperatures. Also, it was observed that the appearance of the pyrophosphate phase enhances the particle size increase. 

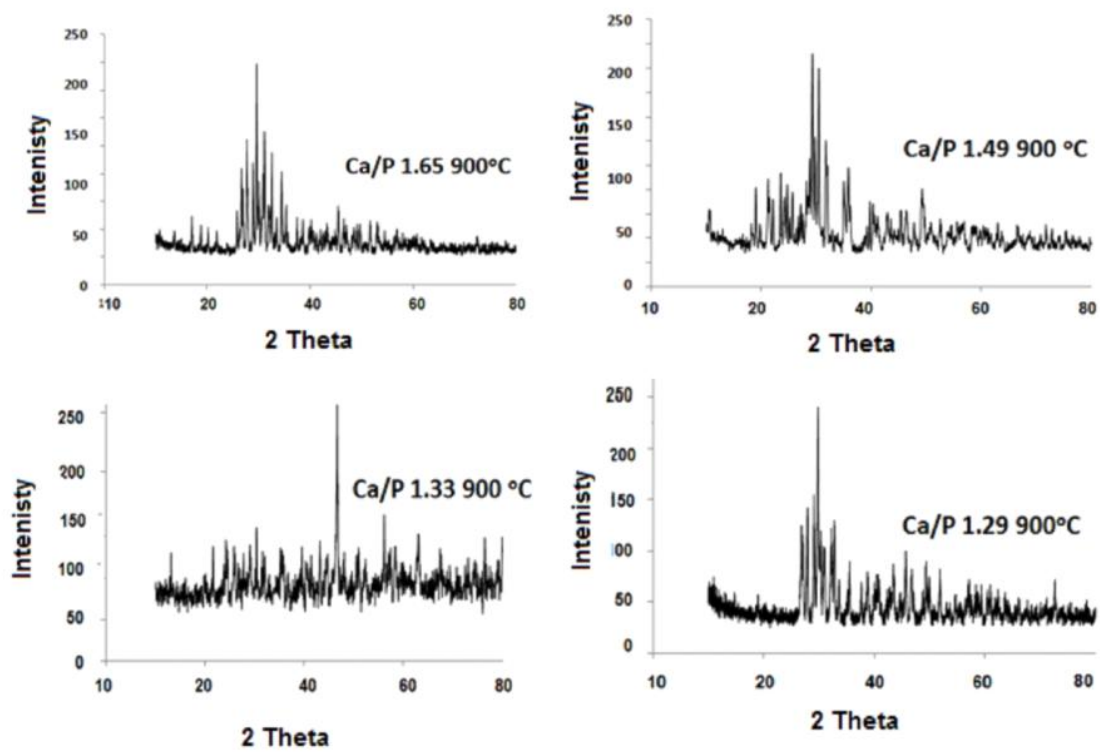

Fig. 2. X-ray diffraction of calcium phosphate ceramics prepared with $\mathrm{Ca} / \mathrm{P}$ ratio ranging from 1.65 to1.29 and calcined at $900^{\circ} \mathrm{C}$.
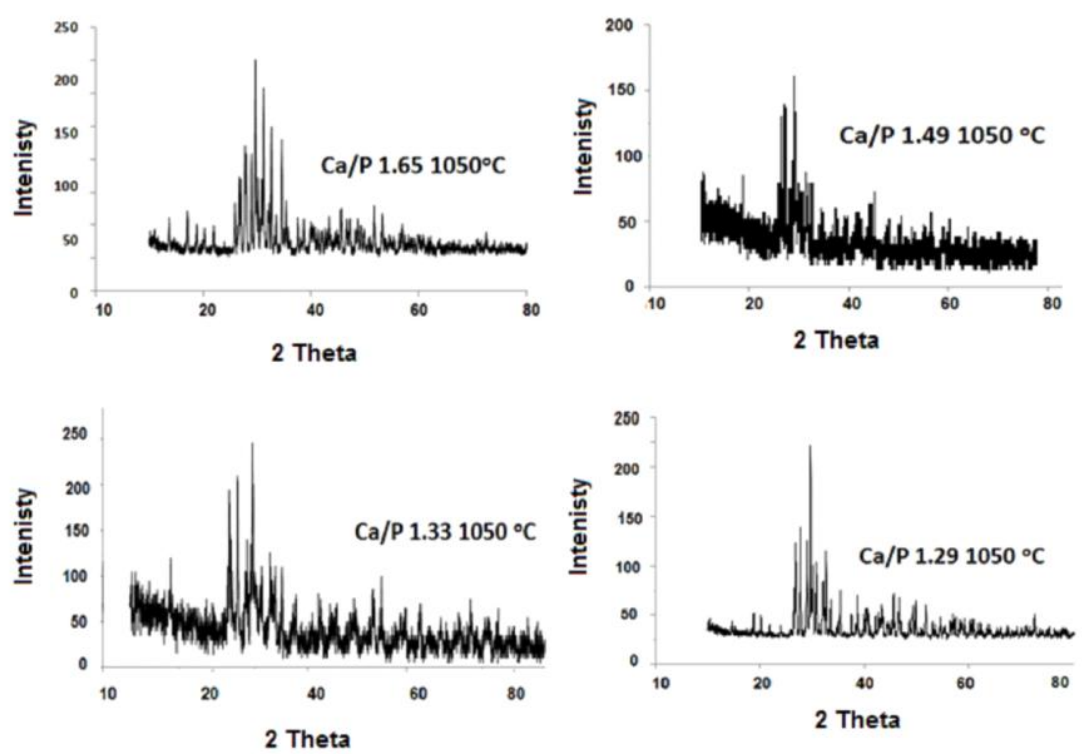

Fig. 3. X-ray diffraction of calcium phosphate ceramics prepared with $\mathrm{Ca} / \mathrm{P}$ ratio ranging from 1.65 to1.29 and calcined at $1050^{\circ} \mathrm{C}$ 

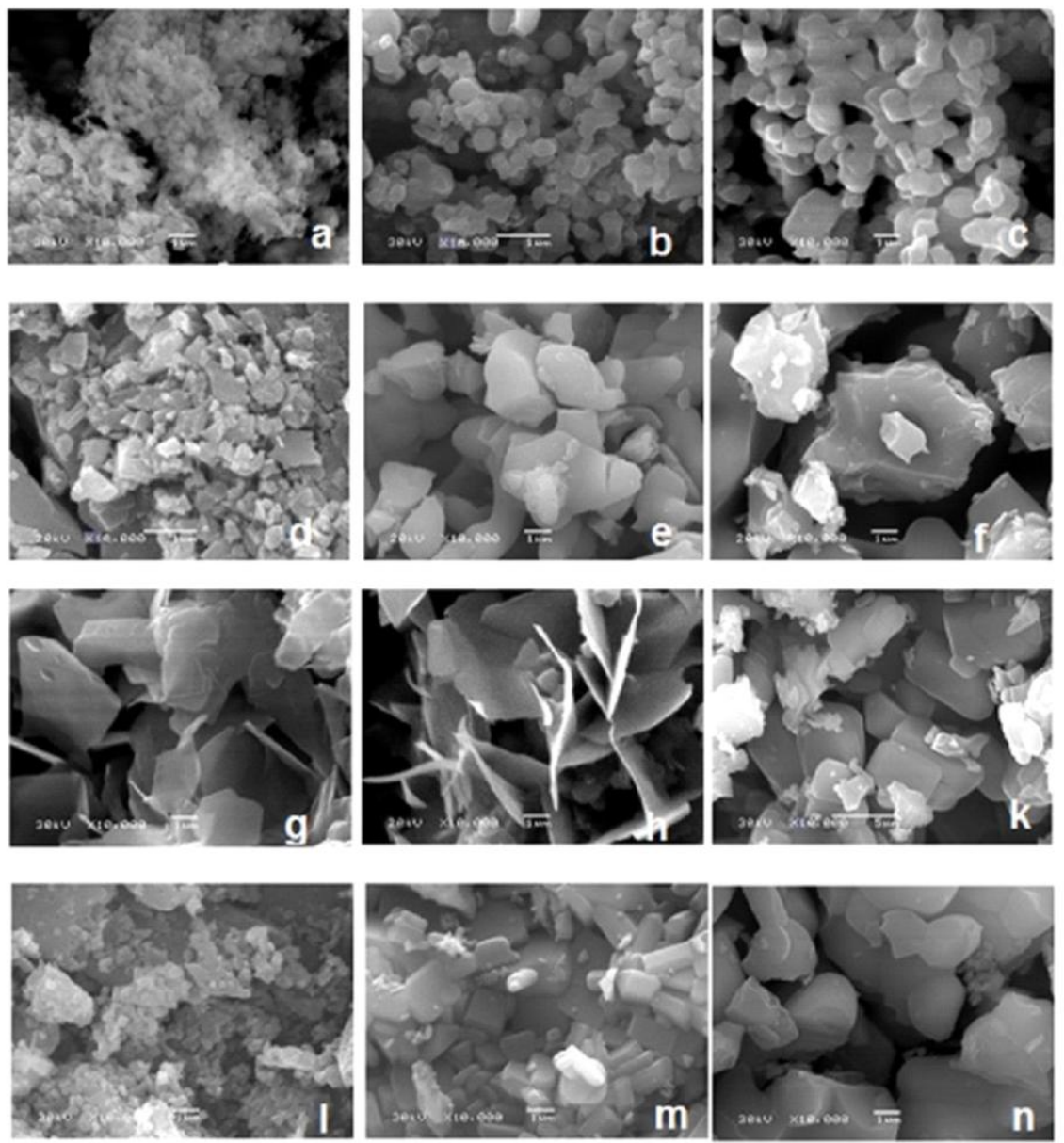

Fig. 4. Scanning electron microscope of calcium phosphate ceramics prepared with $\mathrm{Ca} / \mathrm{P}$ ratio ranging from 1.65 to 1.29 and calcined at $750-1050^{\circ} \mathrm{C}(\mathrm{Ca} / \mathrm{P}$ $=1.65$ at 750,900 and $1050^{\circ} \mathrm{C}$ : $\mathrm{a}, \mathrm{b}$ and $\left.\mathrm{c}\right),(\mathrm{Ca} / \mathrm{P}=1.49$ at 750,900 and $1050^{\circ} \mathrm{C}: \mathrm{d}, \mathrm{e}$ and $\left.\mathrm{f}\right),\left(\mathrm{Ca} / \mathrm{P}=1.33\right.$ at 750,900 and $1050^{\circ} \mathrm{C}, \mathrm{g}, \mathrm{h}$ and $\left.\mathrm{k}\right)$ and $\left(\mathrm{Ca} / \mathrm{P}=1.29\right.$ at 750,900 and $1050^{\circ} \mathrm{C}, \mathrm{l}, \mathrm{m}$ and $\left.\mathrm{n}\right)$

Figure 4 (g-k) represents samples prepared with $\mathrm{Ca} / \mathrm{P}$ ratio 1.33 in which a significant image shape of $\beta$ - TCP for samples at $750{ }^{\circ} \mathrm{C}$ and 900 (Fig. 4-g and Fig. 4-h) respectively ${ }^{(27)}$. In Fig. 4-k, the image showed the appearance of the monoclinic structure of pyrophosphate phase could be noticed. Images in (4.1-n) showed particle size range smaller than that predicted in other $\mathrm{Ca} / \mathrm{P}$ ratios. This relative decrease in particle size could be devoted to the existence of pyrophosphate phase which referred in the literature as the smallest particle size 
among calcium phosphate ceramics as pyrophosphate has the least density among other CPCs ${ }^{(27)}$.

\section{Conclusion}

In the present study calcium phosphate ceramics were prepared using eggshell precursor treated hydrothermally with phosphoric acid. Effect of $\mathrm{Ca} / \mathrm{P}$ ratio as well as the calcination temperature was studied. It was concluded that:

- For $\mathrm{Ca} / \mathrm{P}$ ratio 1.65 at calcination temperature 750 and $900^{\circ} \mathrm{C} \mathrm{HA}$ was the major phase developed and as the temperature increases up to $1050 \beta$-TCP was the major phase detected.

- For $\mathrm{Ca} / \mathrm{P}$ ratio 1.49 at calcination temperature 750 and $900^{\circ} \mathrm{C} \mathrm{HA}$ was the major phase developed with the appearance of minor pyrophosphate phase and as the temperature increases up to $1050^{\circ} \mathrm{C} \beta$-TCP was the major phase also detected with the appearance of pyrophosphate phase.

- For $\mathrm{Ca} / \mathrm{P}$ ratio 1.33 at calcination temperature 750,900 and $1050^{\circ} \mathrm{C}$ pure $\beta$-TCP was detected.

- For $\mathrm{Ca} / \mathrm{P}$ ratio 1.29 at calcination temperature 750,900 and $1050^{\circ} \mathrm{C}$ pyrophosphate phase was developed as a major phase.

The SEM images supported the XRD results showing small particle size for HA and pyrophosphate phases. Also, as the calcination temperature increased the particle size increased. The appearance of pyrophosphate phase accompanied with much more increase in particle size due to its bridging effect.

\section{References}

1. Matsumoto, T., Tamine, K., Kagawa, R., Hamada, Y. Okazaki, M. and Takahashi J., Different behavior of implanted hydroxyapatite depending on morphology, size and crystallinity. Ceramic Society of Japan, 114, 760-762, Doi: org/ 10.2109/ jcersj. (2006).

2. Glimcher, M.J., Molecular biology of mineralized tissues with particular reference to bone. Reviews of Modern Physics, 31(2), 359-420 Doi:org/ 10.1103/ Rev Mod Phys.31(1959).

3. Toshiro, S., Variations in dental enamel crystallites and micro- structure. Journal Oral Bioscience, 48 (2), 85-93(2006). Doi:10.1016/S1349-0079(06)80021-6 , (2006).

4. Park, J.B. and Lakes, R.S., "Biomaterials an Introduction” Plenum Press, New York (1996)

5. Hench, L.L., Bioceramics. J. Am. Ceram. Soc. 8, 1705 -1728 Doi: 10.1111/j.11512916.1998.tb02540.x (1998)

6. Lin, K., Chen, L. and Chang J., Fabrication of Dense Hydroxyapatite Nanobioceramics with Enhanced Mechanical Properties via Two-Step Sintering Process. Int. J. Appl. Ceram. Tech., 9 (3), 479-485, Doi: 10.1111/j.1744-7402. (2012).

Egypt. J. Chem. 59, No. 3 (2016) 
7. Tan, C.Y., Yaghoubi, A., Ramesh, S., Adzila, S., Purbolaksono, J., Hassan, M.A. and Kutty, M.G. Sintering and mechanical properties of MgO-doped nanocrystalline hydroxyapatite. Ceram. Int., 39 (8), 8979-8983 Doi:10.1016/j.ceramint.2013.04.098. (2013).

8. Zhang, H.B., Zhou, K.C., Li, Z.y. and Huang, S.P., Plate-like hydroxyapatite nanoparticles synthesized by the hydrothermal method. J. Phys. Chem. Solids, 70 (1), 243-248, Doi:10.1016/j.jpcs.2008.10.011 (2009).

9. Guo, Y.P., Yao, Y.B., Ning, C.Q., Guo, Y.J. and Chu, L.F., Fabrication of mesoporous carbonated hydroxyapatite microspheres by hydrothermal method. Mater. Lett., 65 (14), 2205-2208,Doi:10.1016/j.matlet.2011.04.057 (2011).

10. Ramesh, S., Tan, C.Y., Tolouei, R., Amiriyan M., Purbolaksono, J., Sopyan, I. and Teng, W.D., Sintering behavior of hydroxyapatite prepared from different routes. Mater. Des. 34, 148-154, doi:10.1016/j.matdes.2011.08.011(2012).

11. Mostafa, N.Y., Characterization, thermal stability and sintering of hydroxyapatite powders prepared by different routes. Mat. Chem. Phys. 94 (2-3), 333-341 Doi:10.1016/j.matchemphys.2005. 05.011 (2005)

12. Padmanabhan, S.K., Balakrishnan, A., Chu, M.C., Lee, Y.J. Kim, T.N. and Cho S., Sol-gel synthesis and characterization of hydroxyapatite nanorods. J. Particuology, 7 (6), 466-470 Doi:10.1016/j.partic.2009.06.008 (2009).

13. Feng, W., Mu-sen, L., Yu-peng, L. and Yong-xin, Q., A simple sol-gel technique for preparing hydroxyapatite nanopowders. Mater.Lett. 59 (8-9), 916-919 Doi:10.1016/j.matlet.2004.08.041(2005).

14. Ibrahim, Amal M., Abd El-Latif, M. M., Behery, H.H. and Selim, M.M., Influence of Si- substitution on the conversion of Hydroxyapatite Nano-particles into $\beta$-Tricalcium phosphate. Alexandria Engineering Journal, 48, 225-231 (2009).

15. Shpak, A.P., Karbovskii, V.L. and Vakh, A.G., Electronic structure of iso-morphically substituted strontium apatite. Journal of Electron Spectro-scopy, 585, 137-140 Doi.org/10.1016/j.elspec.2004.02.056 (2004).

16. Kannan, S., Rebelo, A. and Ferreira, J.M.F., Novel synthesis and structural characterization of fluorine and chlorine co-substituted hydroxyapatites. Journal of Inorganic Biochemistry, 100, 1692-1697Doi:10.1016/j.jinorgbio.2006.06.005, (2006).

17. Landi, E., Celotti, G., Logroscino, G. and Tampieri, A., Carbonated hydroxyapatite as bone substitute. Journal of the European Ceramic Society, 23, 2931-2937, Doi: 10.1016/S0955-2219 (03) 00304-2 (2003).

18. Wu, S.C., Tsou, H.K., Hsua, H.C., Hsua, S.K., Lioud, S.P. and Hoe, W.F., A hydrothermal synthesis of eggshell and fruit waste extract to produce nanosized hydroxyapatite.CeramicsInternational,39,81838188,Doi:10.1016/j.ceramint.2013.03.094 (2013).

19. Chaudhuri, B., Mondal B., Modak D.K., Pramanik K. and Chaudhuri B.K., Preparation and characterization of nanocrystalline hydroxyapatite from egg shell and 
$\mathrm{K}_{2} \mathrm{HPO}_{4}$ solution. Materials Letters, 97, 148-150 Doi:10.1016/j.matlet.2013.01.082 (2013)

20. Lee, S.J., Yoon, Y.S. and Lee, M.H. and Oh N.S., Highly sinterable $\beta$-tricalcium phosphate synthesized from eggshells. Materials Letters, 61 (6), 1279-1282 (2007). Doi:10.1016/j.matlet.2006.07.008

21. Santhosh, S. and Prabu, S.B., Thermal stability of nano hydroxyapatite synthesized from sea shells through wet chemical synthesis. Materials Letters, 97, 121(2013). Doi:10.1016/j.matlet.2013.01.081

22. Correia, R.N., Magalhaes, M.C.F., Marques, P.A.A.P. and Senos, A.M.R., Wet synthesis and characterization of modified hydroxyapatite powders. J. Mater. Sci. Mater. Med. 7, 501-505http://link.springer.com/article/10.1007/BF00705432 (1996).

23. Driessens, F.C.M., Dijk Van, J.W.E. and Borg-greven, J.M.P.M., Biological calcium phosphates and their role in the physiology of bone and dental tissues I. Composition and solubility of calcium phosphates. Calcif. Tissue Res., 26,127-137 http://link.springer.com/article/10.1007/BF02013247 (1978).

24. Metsger, D.S., Rieger, M.R. and Foreman, D.W., Mechanical properties of sintered hydroxyapatite and tricalcium phosphate ceramic. J. Mater. Sci., Mater. Med., 10: 917, http://link.springer.com/article/10.1023/A:1008883809160(1999)

25. Webb, N.C., The crystal structure of $\beta$-Ca2P2O. Acta Crystallographica, 21 (6), 942-948. Doi: 10.1107/S0365110X66004225 (1966)

26. Goloshchapov, D.L., Kashkarov, V.M., Rumyantseva, N.A., Seredinn, P.V., Lenshin, A.S., Agapov, B.L. and Domashevskaya E.P., Synthesis of nanocrystalline hydroxyapatite by precipitation using hen's eggshell. Ceramics International, 39, 4539-4549Doi:10.1016/j.ceramint.2012.11.050 (2013)

27. Bow, J.S., Liou. S.C. and Chen, S.Y., Structural characterization at room temperature synthesized nanosized $\beta$-tricalcium phosphate. Biomaterials, 25, 31553161, DOI:10.1016/j.biomaterials.2003.10.046(2004). 


\section{تشكيل الاطوار وتقييم سيراميكيات فوسفات الكالسيوم المحضرة باستخدام مخلفات قشر البيض أمل مزارع ابراهيم ، منى محمود عبد اللطيف" و محمد محمد عبد المنعم سليم

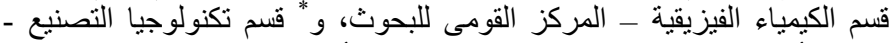 مدينة الأبحاث العلمية و التطبيقات التكنولوجية ـ الأسكندرية ـ مصر.}

تعتبر سير اميكيات فوسفات الكالسيوم واحدة من أهم المواد الحيوية غير العضوية

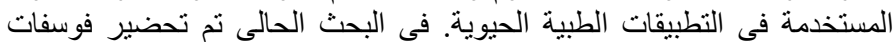

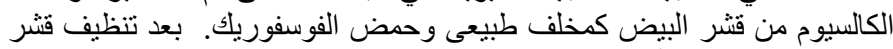

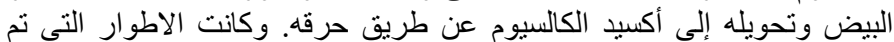

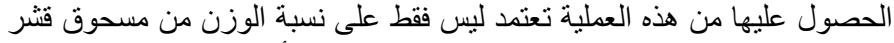

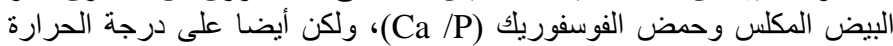

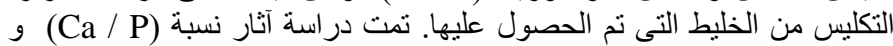
درجة حرارة التكليس وتم تقييم الاطوار التى تم الحصول عليها باستخدام حيود الأشعة السينية الطيفى (XRD) و المجهر الإلكترونى الماسح (SEM). 